\title{
Effect of an Endomycorrhizal Inoculum on the Growth of Argan Tree
}

\author{
Sellal Z. ${ }^{1}$,Ouazzani Touhami A. ${ }^{1}$, Mouden N. ${ }^{1}$, Ouarraqi El M. ${ }^{2}$, Selmaoui K. ${ }^{1}$, Dahmani \\ J. ${ }^{1}$, Benkirane R. ${ }^{1}$, El Modafar Ch. ${ }^{2} \&$ Douira A ${ }^{1}$
}

${ }^{1}$ Laboratoire de Botanique, Biotechnologie et Protection des Plantes, Faculté des Sciences, Université Ibn Tofail, Morocco.

${ }^{2}$ Laboratoire de Biotechnologie, Valorisation et Protection des Agroressources, Faculté des Sciences et techniques Guéliz, Université Cadi Ayyad, Marrakech, Morocco.

\begin{abstract}
The aim of this work is to study the effect of a composite endomycorrhizal inoculum on the growth of argan plants under nursery conditions. Analysis of the obtained results after ten months of inoculation showed a significant effect on the growth of the inoculated plants as compared to the controls. Indeed, the mean values of arial fresh weight (27.54 g) and root (23.64 g).The length $(59.87 \mathrm{~cm})$, the collar diameter $(3.93 \mathrm{~cm})$ and the number of branches (7.37) of the inoculated plants are superior to those observed in the control plants, $13.36 \mathrm{~g}, 13.43 \mathrm{~g}$, $35.83 \mathrm{~cm}, 2.83 \mathrm{~cm}$ and $4.66 \mathrm{~cm}$, respectively. In addition, frequency (100\%), intensity (63.66\%) and arbuscule contents $(51.79 \%)$ and vesicles $(25.52 \%)$ are very important. The roots of the control plants are not mycorrhizal. The mean number of spores formed in the rhizosphere of the inoculated plants is 246 spores per 100 $g$ of soil. These spores are those of 29 endomycorrhizal species belonging to six different genera: Acaulospora, Scutllospora, Pacispora, Glomus, Entrophospora and Gigaspora. Representatives of the Glomus genus are the most dominant.
\end{abstract}

Keywords- Argan tree (Argania spinosa), plants, nursery, inoculation, growth, mycorrhization parameters.

\section{INTRODUCTION}

The argan tree (Argania spinosa L. Skeels), anendemic species to Morocco, is located in the south-west of the country and covers an area of 800.000 ha (Msanda et al., 2005). It is ranked second among forest tree species in Morocco (Ayad, 1989).

Argan tree plays an important ecological role (Le Houérou, 1989) by creation of a favorable climate in the development of a high number of vegetal species participating in the protection against soil erosion especially in the accidental reliefs (Peltier, 1982; Msanda et al., 2005; Achouri et al., 2011). It plays an exceptional economic role (Benzyane, 1989; M'hirit et al., 1998) by ensuring the subsistence of nearly 3 million riparian zones (Benzyane, 1995). Each part of the tree is usable and is a source of income or food. Wood is used as fuel, leaves and fruits as fodder for goats (M'hirit et al., 1998; El Aich et al., 2007). Argan oil, consumed almost exclusively in the region of production, is now widely exported to many countries (Europe, North America, Japan, etc.), as a luxury food product, appreciated for its nutritional and organoleptic qualities, or used in cosmetic products (Nouaïm et al., 2007; Echairi et al., 2008). Despite this exceptional value recognized by the users, the arganeraie has always been subjected to anthropozoic pressure. It regressed mainly because of clearing for crops and the extension of towns (Elyousfiand Benchekroun, 1992). Between 1969 and 1986, it lost nearly 9900 hectares (Benabid and Elyousfi, 1989). In parallel with the retreat of the argan tree, natural regeneration by sowing is very rare (Boudy, 1952) or absent. This absence is due to the excessive harvesting of the fruit, which the special legislation of the argan tree authorizes and which is part of the broad right of enjoyment granted to the users, it is also due to the grazing of the rare seedlings resulting from the germination of some remaining nuclei by livestock (Boudy, 1950). Climatic conditions are also not conducive to seed germination (Zahidi and Bani-Aameur, 1996).

The efforts of the Moroccan forestry services in the field of reforestation based on argan tree are hampered by the difficulty of resuming seedlings produced in nurseries (Ferradous et al., 1997). According to these authors, several reasons can explain the observed failures: precipitation deficit, inadequate of the used plants. The improvement of plant production techniques at the nursery level is an unavoidable step and must imperatively be mastered (Lamhamedi et al., 2000). Controlled mycorrhization of seedlings at nursery (Nouaïm and Chaussod, 1994), for example, could potentially increase the success of transplants and the initial growth of trees (Echairi et al., 2008).

The argan tree has the ability to establish a symbiotic association with AM fungi (Achouri et al., 2011; Nouaim and Chaussod, 1996). Arbuscula rmycorrhizae are found 
in more than $70 \%$ of vascular plant species (Fortin et al., 2008) and allow the extension of the absorption surface and the volume of the soil explored, well beyond the zone of depletion of the rhizosphere (Sylvia, 1986). This type of mycorrhizae also allows a better improvement of the assimilation of the nutrients in particular the $\mathrm{P}$ and $\mathrm{N}$ (Toro et al., 1997; Haougui et al., 2013), especially in arid and semi-arid environments, improved aggregation and soil stability (Rillig and Mummey, 2006) and protection against phytopathogens (Newsham et al., 1995; Pozo et al., 1999 ; Dalpé, 2005; Tahat et al., 2010). AMF also help plants to develop in arid and semi-arid areas via the reduction of drought stress (Augé, 2001; Herrera et al., 1993; Roldan et al., 1996b; Barea et al., 2008; Honrubia, 2009), improvement of the physicochemical and biological properties of soils (CarrilloGarcciaet al., 1999; Rillig and Mummey, 2006; Schmid et al., 2008) and other environmental stresses (Barea et al., 2007; Ouahmane, 2007; Martínez-García and Pugnaire, 2009; Martínez-García, 2010).

The mycorhization of argan plants is therefore an interesting way to explore for the restoration of degraded areas (Ammari et al., 2006). The higher diversity of endomycorrhizal fungi at the rhizosphere of the argan tree growing in different areas of south west Morocco was been revealed (Sellal et al., 2016).
The present work aims to study the effect of a native composite endomycorrhizal inoculum on the growth and development of argan tree plants in nurseries.

\section{MATERIALS AND METHODS}

\section{1- Vegetal Material}

The used argan plants for inoculation are four months old. They were raised in a nursery on a substrate, disinfected Mamora's soil.

\section{2- Inoculum production and multiplication:}

The barley (Hordeum vulgare), mycotropic plant, was chosen for the production of a composite inoculum based on arbuscular mycorrhizal mushrooms belonging to six (6) genera: Acaulospora, Glomus, Scutellospora, Entrophospora, Pascispora, Gigaspora. Barley grains were disinfected with $5 \%$ sodium hypochlorite for 2 minutes and sprouted in plastic cups filled with a mixture of disinfected sand and soil of the argan tree rhizosphere. All the pots were placed in a greenhouse and watered regularly with distilled water.

After three months of culture, the frequency and intensity of barley mycorrhization were estimated using the method of Phillips and Hyman (1970).

\section{3- Physico-chemical soil parameters}

The used soil in all trials is that of the Mamora's forest, the characteristics of which are given in Table 1.

Table.1: Chemical characteristics of the Mamora's soil

\begin{tabular}{|l|l|l|l|l|l|l|l|}
\hline $\begin{array}{l}\text { Physico- } \\
\text { chemical soil } \\
\text { parameters }\end{array}$ & pH & Organicmatter & Nitrogen(\%) & $\begin{array}{l}\text { Phosphorus } \\
\mathbf{P}_{\mathbf{2}} \mathbf{O 5}(\boldsymbol{\%})\end{array}$ & $\begin{array}{l}\text { Potassium } \\
\mathbf{K}_{2} \mathbf{O} \\
(\mathbf{m e q} / \mathbf{1 0 0 g})\end{array}$ & $\begin{array}{l}\text { Magnesium } \\
(\mathbf{M g}) \\
(\mathbf{m e q} / \mathbf{1 0 0 g})\end{array}$ & $\begin{array}{l}\text { Calcium }(\mathbf{C a}) \\
(\mathbf{m e q} / \mathbf{1 0 0 g})\end{array}$ \\
\hline Mamora's soil & 7.53 & 0.7 & 0.05 & 0.239 & 0.15 & 0.20 & 7351.5 \\
\hline
\end{tabular}

\section{4- Inoculation}

Argan plants, 4 months old, were transplanted into pots containing $50 \%$ of the soil of the disinfected Mamora and $50 \%$ of the inoculum (soil and mycorrhizal roots). The control plants were planted only on the sterilized soil of Mamora's forest. All plants are deposited in a greenhouse and irrigated every three days with distilled water for plants inoculated with AM fungi, either with tap water for other inoculated plants.

\section{5- Evaluation of mycorrhization parameters}

After ten (10) months of inoculation, colonization of the roots of the argan tree plants with the AMF was carried out using the root staining technique of Philips and Hayman (1970), modified by Koské and Gemma (1989).

The fine roots of the argan plants, recovered from the culture substrate, were washed with tap water and cut into fragments of $1 \mathrm{~cm}$ in length, immersed in a $10 \% \mathrm{KOH}$ solution and placed in an oven at $90^{\circ} \mathrm{C}$. for one hour. At the end of this period, the roots are rinsed with sterile distilled water and transferred to a solution of $\mathrm{H}_{2} \mathrm{O}_{2}$ (hydrogen peroxide) for 20 minutes at $90^{\circ} \mathrm{C}$ until the roots were bleached. The roots were then rinsed and then stained with $0.05 \%$ cresyl blue by submersion at $90^{\circ} \mathrm{C}$ for 15 min.

Thirty fragments, chosen at random for microscopic observation, were used to estimate mycorrhization parameters: Frequency of mycorrhization $(\mathrm{F} \%)$, intensity of mycorrhization (M\%) and arbuscular (A\%) and vesicular (V\%) contents, According to the mycorrhization index of Trouvelot et al (1986).

\section{6- Spore extraction}

The spores were extracted according to the wet sieving method described by Gerdemann and Nicolson (1963). In a $1 \mathrm{~L}$ beaker, $100 \mathrm{~g}$ of each composite soil sample is submerged in $0.5 \mathrm{~L}$ of running water and stirred for $1 \mathrm{~min}$ 
with a spatula. After 10 to 30 seconds of settling, the supernatant was passed through four superposed sieves with decreasing meshes $(500,200,80$ and $50 \mu \mathrm{m})$. This operation is repeated twice. The content retained by the 200,80 and $50 \mu \mathrm{m}$ sieves was distributed in two tubes and centrifuged for $4 \mathrm{~min}$ at $9000 \mathrm{rpm}$. The supernatant is discarded and a viscosity gradient was thus created by adding $20 \mathrm{ml}$ of a $40 \%$ sucrose solution to each centrifuge tube (Walker et al., 1983). The mixture was rapidly stirred and the tube returned to the centrifuge for $1 \mathrm{~min}$ at $9000 \mathrm{rpm}$.

The mixture is rapidly stirred and the tube returned to the centrifuge for $1 \mathrm{~min}$ at $9000 \mathrm{rpm}$, the obtained substrate is rinsed with distilled water to remove sucrose and then disinfected with an antibiotic solution (Streptomycin). The spores were then recovered with a little distilled water in an erlenmeyr.

\section{7- Sporesidentification}

The isolated spores were identified according to the morphological characteristics (color, shape, size and some characteristic structures, sporuloussaccule, germination shield, bulb and suspensor), referring to the determination key of Schenk and Perez (1990) and the INVAM website.

\section{8- Evaluation of agronomic parameters}

After ten (10) months of greenhouse cultivation, the measurements concerned the height of the stem from the collar to the apex, collar diameter, number of twigs, aerial and root biomass. The mycorrhization parameters were also measured on thirteen colored fine root samples.

\section{9- Statical analysis.}

Analysis of the variance and of the mean comparisons using the LSD test $(\mathrm{p}=5 \%)$ were performed using the software STATISTICA program. (ANOVA1).

\section{RESULTS}

After ten months of greenhouse cultivation, the length of mycorrhizal plants reached $59.87 \mathrm{~cm}$ while that of the control plants was $35.83 \mathrm{~cm}$ (Table 2). The average diameter of the stems and the number of branches developed in the mycorrhizal plants far exceeded those of the control plants, respectively, $3.93 \mathrm{~cm} / 7.37$ and 2.83 $\mathrm{cm} /$ 4.66. Similarly, for the fresh weight of the root system and that of the aerial part of the inoculated plants are greater than those noted in the control plants, the gains are respectively $10.21 \mathrm{~g}$ and $14.18 \mathrm{~g}$.

Table.2: Effect of the inoculation on the growth of the argan plants.

\begin{tabular}{|c|c|c|}
\hline Measured parameters & $\begin{array}{c}\text { Inoculated } \\
\text { Plants }\end{array}$ & control \\
\hline $\begin{array}{c}\text { Length of the aerial plant } \\
(\text { cm) }\end{array}$ & $59.87^{a}$ & $35.83^{b}$ \\
\hline $\begin{array}{c}\text { Average diameter at the } \\
\text { collar of the main axis }(\mathbf{c m})\end{array}$ & $3.93^{a}$ & $2.83^{b}$ \\
\hline $\begin{array}{c}\text { Biomass of the aerial part } \\
(\boldsymbol{g})\end{array}$ & $27.54^{a}$ & $13.36^{b}$ \\
\hline Rootbiomass (g) & $23.64^{a}$ & $13.43^{b}$ \\
\hline $\begin{array}{c}\text { Average number of twigs } \\
\text { formed per plant }\end{array}$ & $7.37^{a}$ & $4.66^{b}$ \\
\hline \multicolumn{2}{|c}{} \\
\hline
\end{tabular}

Two results, same line, accompanied by the same letter do not differ significantly at the $5 \%$

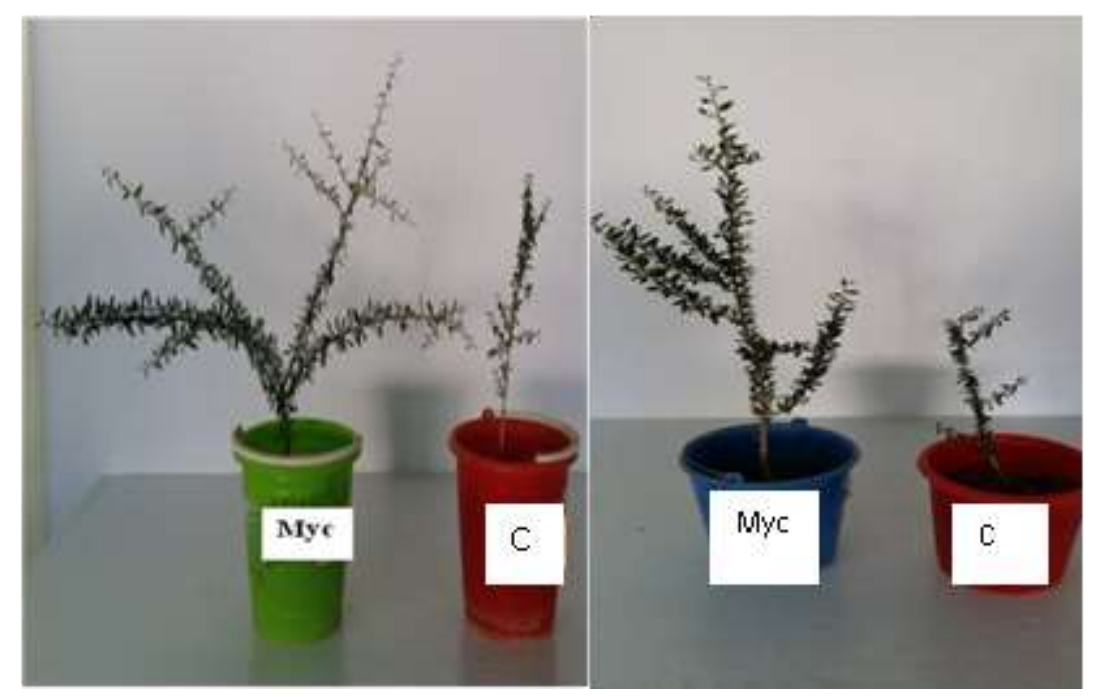

Fig.1: Effect of inoculation on thegrowth of the aerial part of the argan plant, 10 days after culture: Myc: mycorrhizal plants, $C$ : controls. 


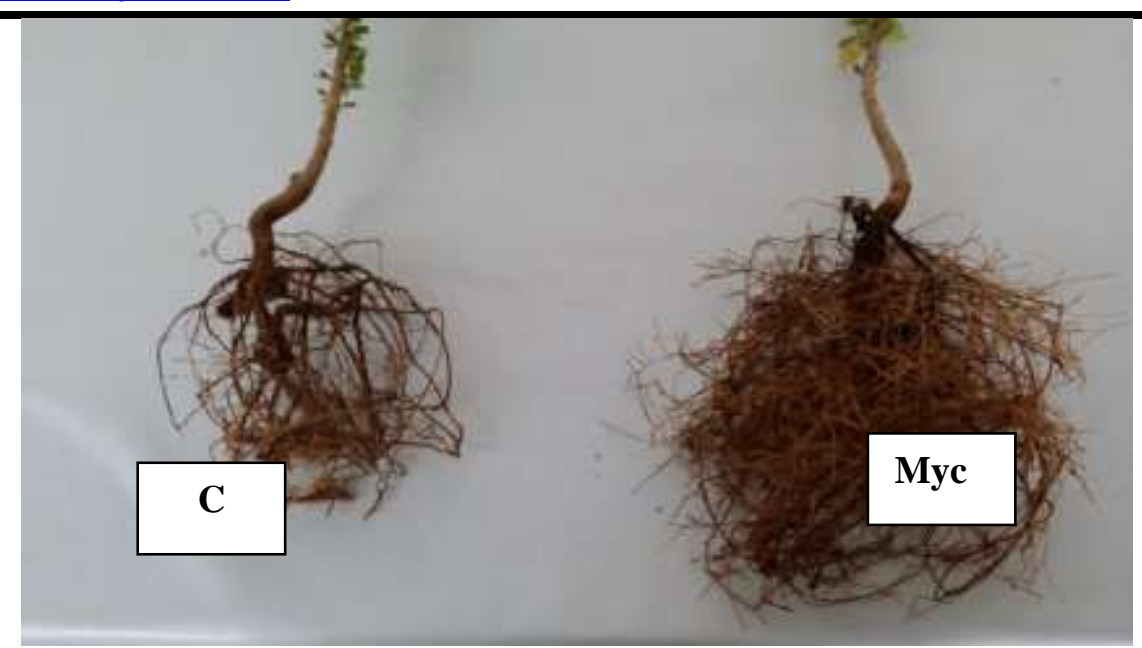

Fig.2: Effect of inoculation on the development of the root system of the argan plants: C: Control;Myc:mycorrhizal plant

Microscopic observation of the fragments of argan roots inoculated with mycorrhizae revealed the presence of structures of arbuscular endomycorrhizae: vesicles, arbuscules, intra and extracellular hyphae and spores (figure 3). MA colonization was translated by a mycorrhizal frequency (F\%) of $100 \%$ and a mycorrhizal intensity of $63.66 \%$. While the roots of the control plants showed no mycorrhizal structure. The roots of the inoculated plants also showed a high level of arbuscules and vesicles of $51.79 \%$ and $25.52 \%$ (figure 4). Similarly, the mean number of spores in the rhizosphere of mycorrhizal plants is 246 spores / $100 \mathrm{~g}$ of soil. The identification of these isolated spores revealed the presence of 29 species belonging to six genera: Glomus, Acaulospora, Scutellospora, Pacispora, Entrophospora and Gigaspora. The Glomus genus was the dominate, it was represented by thirteen (13) species, namely: Glomus aggregatum, G. ampisporum, G. clarum, G. claroideum, G. deserticola, Glomus $\mathrm{sp} 1, \quad G$. etunicatum, $G$. geosporum, G. intraradices, G. macrocarpum, Glomus $\mathrm{sp} 2$, Glomus versiforme, Glomus minitum. The Entrophospora and Acaulospora genera were represented by five species which were respectively, Entrophospora infenquens and Entrophospora nevadensis, Entrophospora sp1, Entrophospora sp2 and Entrophospora sp3, Acaulospora denticulata, Acaulospora reducta, Acaulospora sp1 and Acaulospora sp2, Acaulospora sp3. As regards the genus Scutellospora, it is represented by four species: Scutellospor acastanea, Scutellospora pellucida, Scutellospora sp1 and Scutellospora sp2, the Pacispora and Gigaspora genera are represented by a single species respectively: Pacispora sp. and Gigaspora. 


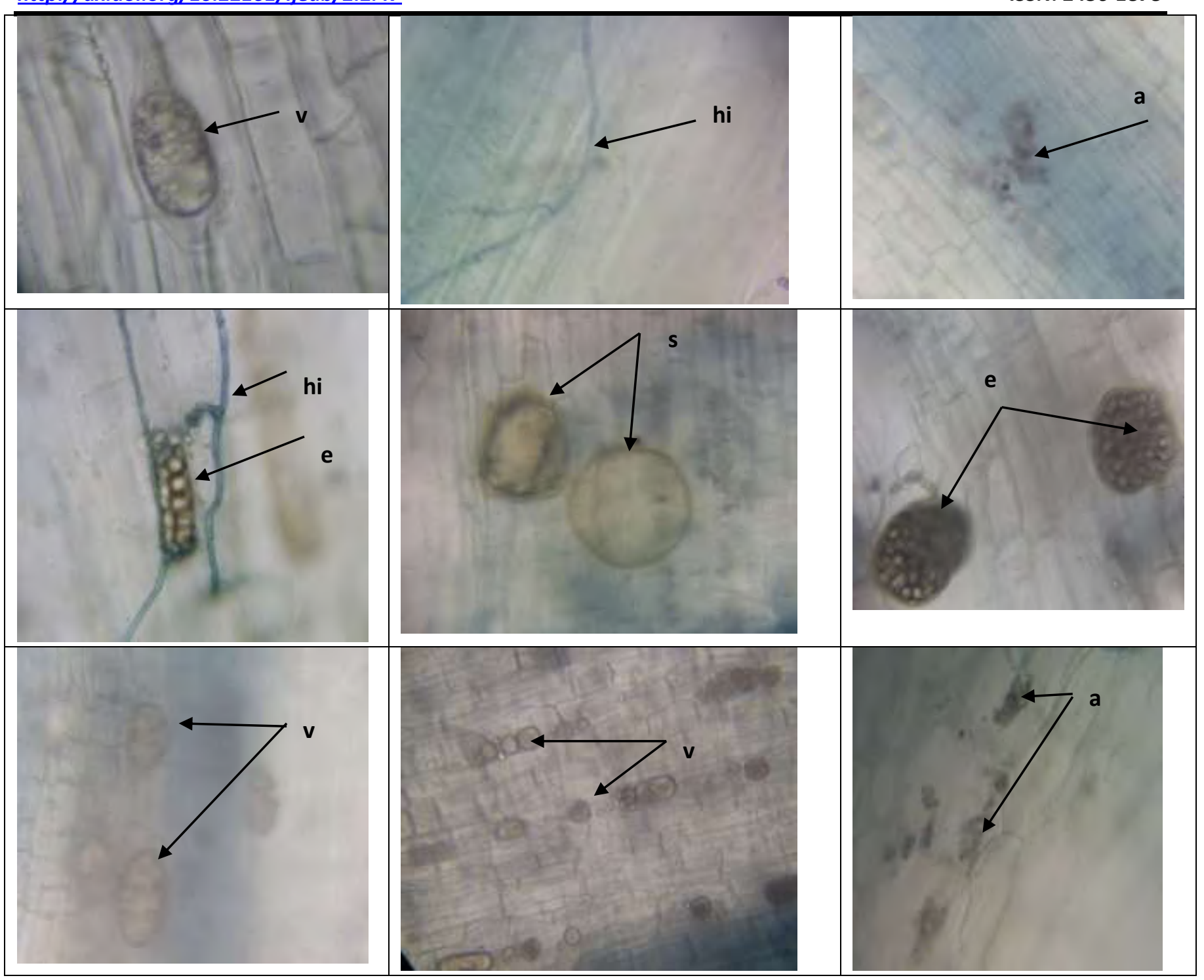

Fig.3: Different structures of arbuscular mycorrhizae in the roots of inoculated argan plants: a: arbuscule; e: endophyte; hi :internal hyphae; V: vesicule $(G . \times 400)$.

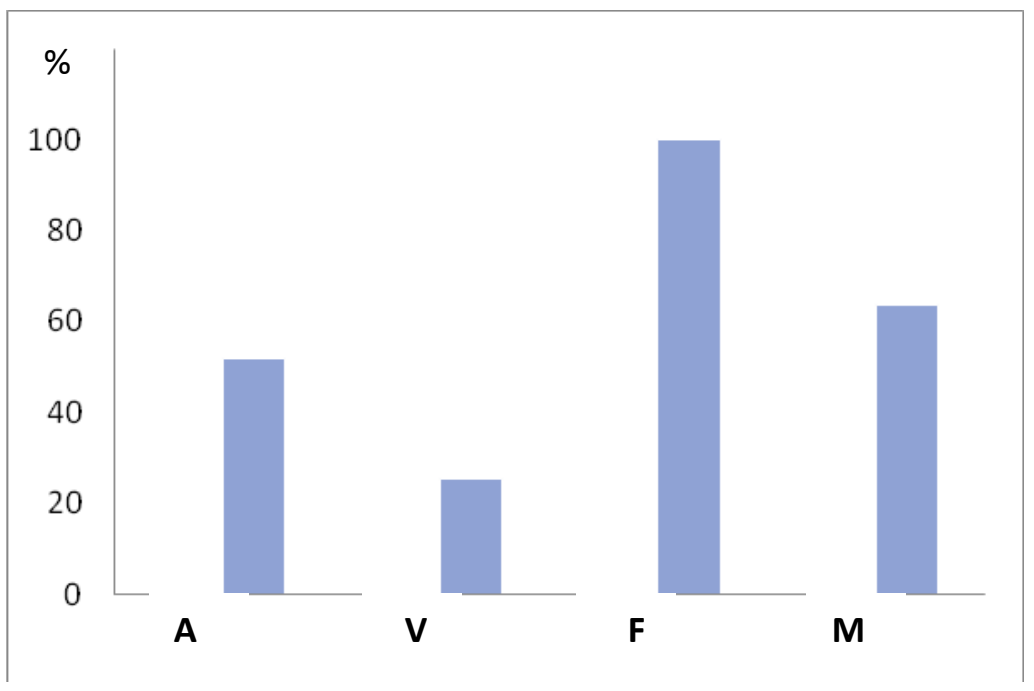

Fig.4 : Mycorrhization Parameters of the argan roots after ten (10) months of culture: mycorrhizal Frequency (F\%) and Intensity (M\%), Arbuscular (A\%) and vesicular contents (V\%). 


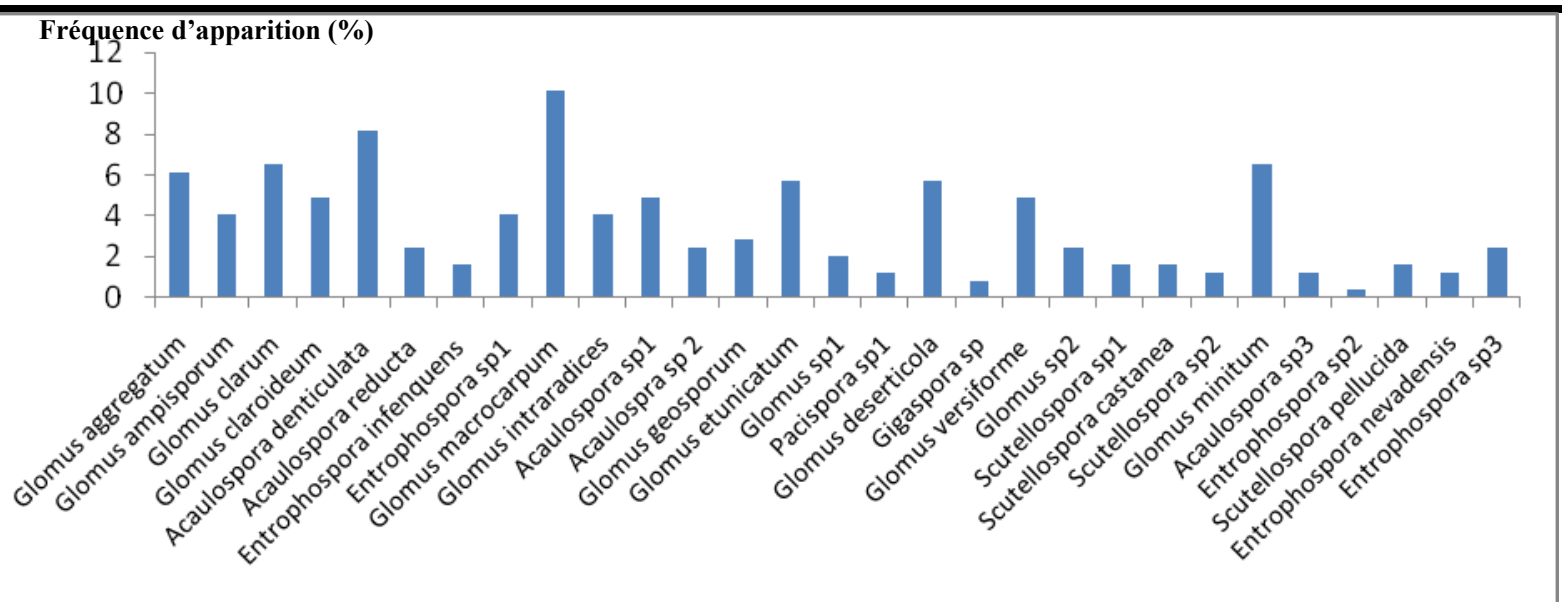

Fig.5:Isolation frequency of mycorrhizal species at the soil level of argan plants inoculated with mycorrhizae after ten (10) months of culture.
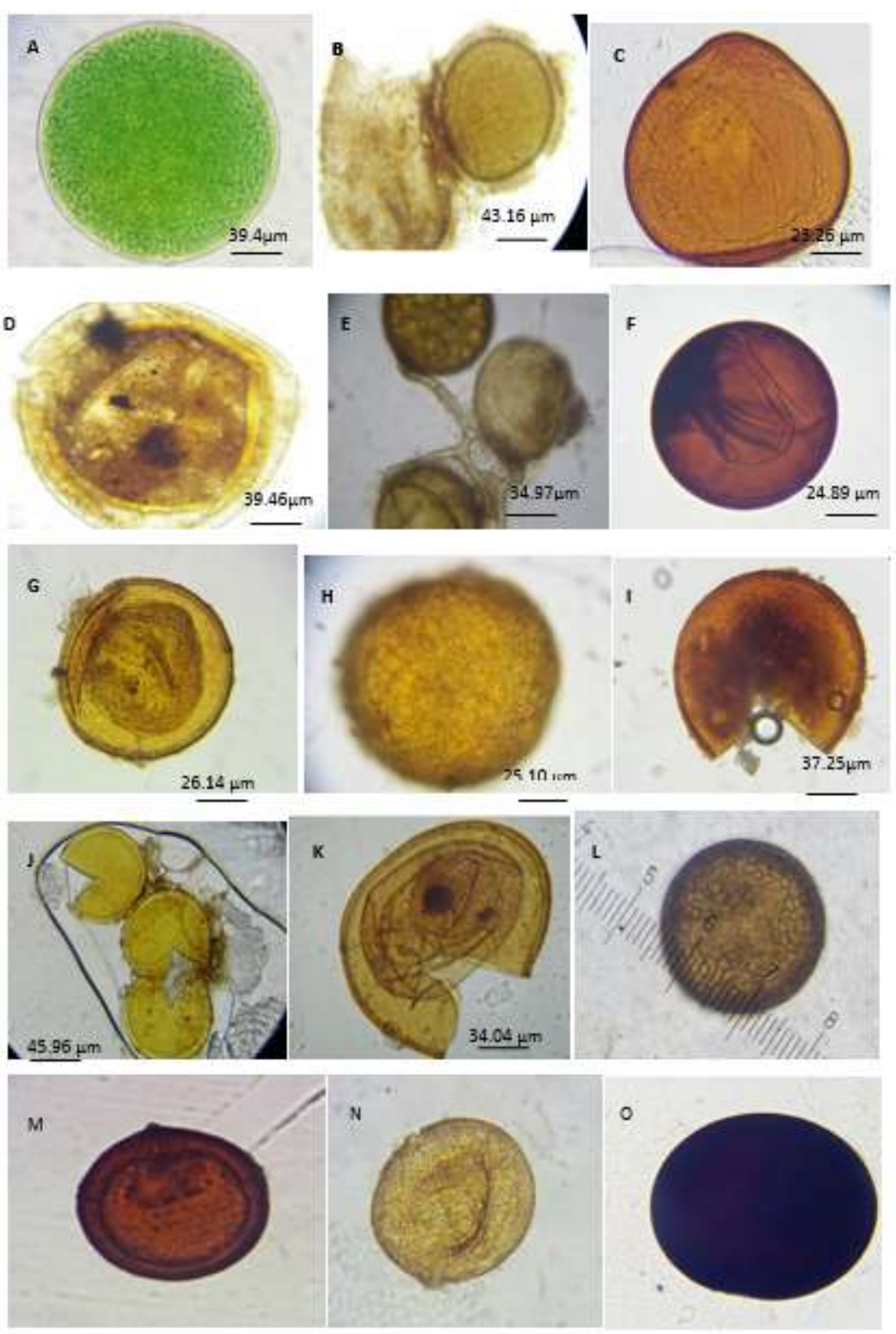

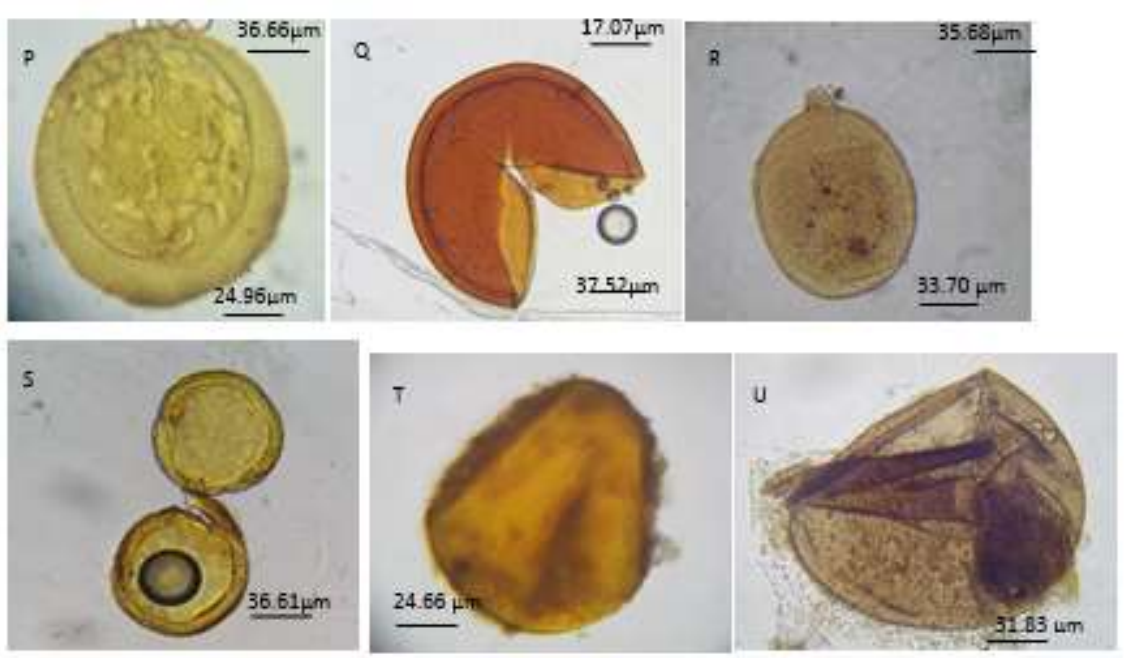

Fig.6: Some species of endomycorrhizal fungi isolated from the argan tree rhizosphere: A : Gigaspora sp.; B :

Entrophospora nevadensis; $\boldsymbol{C}:$ Scutellospora sp1; D: Entrophospora sp1; E : Glomus ampisporum ; $\boldsymbol{F}:$ Scutellospora

biornata; ; $\boldsymbol{G}:$ Glomus etunicatum ; $\boldsymbol{H}:$ Acaulospora denticulata ; I : Scutellospora pellucida ; J : Glomus.

macrocarpum ; $\boldsymbol{K}$ : Entrophospora sp2 ; L : Acaulospora reducta ; $\boldsymbol{M}$ : Glomus macrocarpum ; $\boldsymbol{N}:$ Acaulospora sp1 ; $\boldsymbol{O}$ :

Glomus deserticola ; $\boldsymbol{P}:$ Glomus sp2;Q: Glomus aggregatum; $\boldsymbol{R}:$ Glomus sp3; $\boldsymbol{S}:$ Glomus intraradices $; \boldsymbol{T}$ :

Entrophospora sp 3; $\boldsymbol{U}:$ Acaulospora sp2.

\section{DISCUSSION AND CONCLUSION}

The present study shows that the growth of the argan plants has been improved by the presence of endomycorrhizal fungi at the level of the culture substrate. Other authors (Nouaim and Chaussod, 2002; Bousselmane et al., 2002; Echairi et al., 2008) reported the beneficial effect of mycorrhizal inoculation on the growth of argan tree plants from cuttings or seedlings. Thus, the response to mycorrhization of seedlings from seedlings has already been observed by other authors (Bâ et al., 2001; Turjaman et al., 2006).

These results are consistent with those of Laminou (2010) who show that mycorrhizal inoculation stimulates the growth of sorghum (Sorghum bicolor L. Moench) and cowpea (Vigna unguiculata (L.) Walp). Contrary to the work of Plenchette et al. (2000), who observed that mycorrhization of millet by Glomus aggregatum did not stimulate its growth.

The results on biomass showed that the productions of fresh matter are improved by inoculation, with significant differences compared to the controls. Similar responses were reported in the case of Leucaena inoculated with Glomus sp., of clover inoculated with G. mosseae and, in the case of Acacia nilotica and Acacia senegal inoculated with a mycorrhizal complex of native strains (Dixon et al., 1993; Laaziza et al., 2003; Laminou et al., 2009).

The mycorrhizal argan plants showed a well-developed and highly branched root system. This important root branching in mycorrhizal plants has also been reported in other plant species: Oleaeuropea (Citernesi et al., 1998;
Chliyeh et al., 2014), Prunus cerasifera (Berta et al., 1995), Vitis vinifera (Schellenbaum et al.,1991), date palm (Sghir et al., 2014), carob tree (Talbi et al., 2016) and Fragaria ananassa (Norman et al., 1996). Caravaca et al. (2003) showed that the root mass of Dorycnium pentaphyllum plants inoculated with Glomus intraradices increased by $116 \%$ compared to that observed in non-mycorrhizal plants. Nouaim and Chausoud (2002) showed that the inoculation of argan tree plants by Glomus intraradices resulted in a better efficiency of the root system. Indeed, this stimulation of root growth has been able to improve the absorption of water and mineral nutrition (Fidelibus et al., 2000; Fester et al, 2002; Derkowska et al., 2008; Stavros et al., 2011), which resulted in a good development of the vegetative mass. El Mrabet et al. (2014) showed the effect of inoculation of argan plants by endomycorrhizae on the biomass of argan plants. At the end of the growth period, mycorrhization resulted in a $169 \%$ gain in aerial biomass compared to the control plants.

Through various physiological mechanisms (Augé, 2001), the mycorrhizal symbiosis can help the young plants to face the difficult conditions of arid zones (Nouaîm and Chaussod, 1996). The ability of the inoculum to adapt to its edaphic environment, its extra-root development and its competitiveness with the indigenous microflora are important parameters (Caravaca et al., 2003). Duponnois et al. (2005) showed that the more inoculated plants are robust compared to non-inoculated plants, the more they could survive by showing a high capacity to resist environmental conditions. 
In plantation trials, several authors have obtained significant improvements in the recovery rates, in very unfavorable environments, of many forest species such as chestnut (Strullu et al., 1986), oack (Boutekrabt et al., 1990), pine and hazel (Strullu and Plenchette, 1991). The contribution of fungi symbiotes improves the assimilation of water and nutrients by the plants and consequently contributes to an improvement in their recovery rate especially during the first months following their establishment in natural conditions (Nouaim, 1994). The establishment and multiplication of endomycorrhizal fungi in the roots of the argan plants are probably at the origin of root and vegetative mass development. The frequency and intensity of mycorhization of argan plants root after ten months of cultivation were $100 \%$ and $63.66 \%$. The work of Nouaim et al. (1994) showed that the frequency and intensity of mycorrhization in argan plants multiplied in vitro by micro-propagation were respectively $95 \%$ and $60 \%$.

Elmrabet et al. (2014) showed that the effect of inoculation on the biomass of argan tree plants was positively correlated with root colonization by AM fungi. Studies by Bousselmane et al. (2002) showed that the argan tree showed a high rate of mycorrhization of the order of $70 \%$, three (3) months after inoculation with a Glomus sp1 strain and one (1) month later by the Glomus sp2 strain. According to the same authors, the delay noted in the infection by the Glomus sp2 strain can be attributed to its weak infectivity. According to Plenchette \& Fardeau (1988), the rate and duration of infection depend on three factors, namely the host used, the infectivity of the mycorrhizogenic fungus and the culture substrate.

The presence of a large number of spores (246 spores per $100 \mathrm{~g}$ of soil) in the rhizosphere of the inoculated plants is indicative of an important activity of the endomycorrhizal symbiosis. The species identified are of the order of 29 endomycorrhizal species belonging to six different genera: Acaulospora, Scutllospora, Pacispora, Glomus, Entrophospora and Gigaspora. The Glomus genus is the most dominant. According to Stutz et al. (2000), these representatives are the most adapted to fluctuations in environmental conditions.

The study revealed that indigenous AM fungi, based on an indigenous composite endomycorrhizal inoculum, could be considered as a preferential inoculation tool to ensure the re-establishment of native shrub species in degraded soils in semi-arid areas, the case of the argan tree.

The mycorrhization of this plants species in the nursery before the transfer to the perimeter of plantation, as demonstrated in this study, should be a mandatory step in any reforestation or silviculture program.

\section{REFERENCES}

[1] Achouri A., Aroui A., Defaa C., El mousadik A., Msanda F., 2011. Effet de la mise en défense sur la richesse floristique et la densité dans deux arganeraies de plaine. Premier Congrès International sur l'Arganier Acquis et perspectives de la recherche scientifique, Agadir, le 15/12/2011.

[2] Ammari Y., Lamhamedi M.S., Akrimi N., et Zine El Abidine A., 2006. Qualités physiologiques de jeunes plants de Pin d'Alep élevés en pépinière moderne sur différents substrats à base de compost. Geo Eco Trop., 30(1):11-24

[3] Augé R. M., 2001. Water relations, drought and vesicular-arbuscular mycorrhizal symbiosis. Mycorrhiza, 11, 3-42. http://dx.doi.org/10.1007/s005720100097

[4] Ayad A., 1989: Présentation de l'arganeraie. Formation forestière continue. Thème: l'arganier. A.E.F.C.S., Rabat.

[5] Bâ A., Guissou T., Duponnois R., 2001. Mycorhization contrôlée et fertilisation phosphatée : application à la domestication du jujubier. Fruits : 56 :261-9.

[6] Barea JM., Palenzuela J., Cornejo P., Sánchez I., Navarro C., Quiñones P B., Azcón R., Ferrol N., Azcón-Aguilar C., 2007. Significado, diversidad e impacto de los hongos de las micorrizasarbusculares en ambientesmediterráneos. In: J. M. Barea-Azcón, M. Moleón, R. Travesí, E. Ballesteros, J. M. Luzón, \& J. M. Tierno (Eds.), Biodiversidad y conservación de fauna y flora en ambientes Mediterráneos (pp. 155-185). Granada: Sociedad Granatense de Historia Natural.

[7] Barea J.M., Ferrol N., Azcón-Aguilar C., \&Azcón R., 2008. Mycorrhizal symbioses. Series. In: P. J. White, \& J. P. Hammond (Eds.), The ecophysiology of plant-phosphorus interactions. Plant Ecophysiology, Vol. 7 (pp. 143-163). Dordrecht: Springer.

[8] Benabid A. \&Elyousfi M., 1989. Dégradation du couvert forestier dans le sud Marocain : cas de l'arganeraie d'Admine. Revue Abaad Fykrya. Assoc. Aut. Maroc. Edit., Trad. Et Public., Rabat, (en arabe), $n^{\circ} 2: 35-38$.

[9] Benzyane M., 1989. Estimation de la biomasse et étude de la croissance de l'Arganier ( Argania spinosa (L.) Skeels) dans le plateau de Haha (Essaouira). - Rabat: Institut agronomique et vétérinaire Hassan II,. —224 p. +annexes (Mémoire de fin d'étude).

[10] Benzyane M., 1995. Le rôle socio-économique et environnemental de l'arganier, actes des Journées d'étude sur l'arganier, Essaouira (Maroc), 29-30 septembre 1995. 
[11] Berta G., Trotta A., Fusconi A., Hooker JE., Munro M., Atkinson D., Giovannetti M., Morini S., Fortuna P., Tisserant B., Gianinazzi-Pearson V., Gianinazzi S., 1995. Arbuscular mycorrhizal induced changes to plant growth and root system morphology in Prunus cerasifera .Tree Physiol., 15: 2816293.

[12] Boudy P., 1950. Monographie et traitement de l'arganier. In : Monographie et traitements des essences forestières, Paris, Ed. Larose, tome II, fascicule I, 382-416.

[13] Boudy P., 1952 Guide forestier en Afrique du Nord, Paris, France.

[14] Bousselmane F., Achouri M., Kenny L., 2002. Effet des mycorhizes à vésicules et arbuscules sur la croissance et la nutrition de l'arganier (Argania spinosa L.), Revue Marocaine des Sciences Agronomiques et Vétérinaires, 22(4), 193-198. http://agrimaroc.net.sci-

hub.org/actes/index.php/Actes_IAVH2/article/downl oad/184/163.

[15] Boutekrabt A., Chevalier G., Pargney J.C ., Dexheimer J., 1999 .Mycorhization par Tuber melanosporum Vitt de vitroplants de Quercus robur L et Quercus pubescens Willd. Agronomie, 2: 127132.

[16] Caravaca F., Barea J.M., Palenzuella J., Figueroa D., Alguacil M.M., Roldan A., 2003. Establishment of shrub species in a degraded semiarid site after inoculation with native or allochthonus arbuscular mycorrhizal fungi. Appl. Soil Ecol., 22 : 103-11.

[17] Carrillo-García A., León de la Luz J. L., Bashan Y., \& Bethlenfalvay G. J., 1999. Nurse plants, mycorrhizae, and plant establishment in a disturbed area of the Sonoran desert. Restoration Ecology, 7, 321- $\quad 335 . \quad$ http://dx.doi.org/10.1046/j.1526100X.1999.72027.x

[18] Chliyeh M., OuazzaniTouhami A., Filali- Maltouf A., El Modafar C., Moukhli A., Oukabli A., Benkirane R., Douira A., 2014. Effect of a composite endomycorrhizal inoculum on the growth of olive trees under nurseries conditions in Morocco. International Journal of Pure and Applied Bioscience, 2(2):1-14.

[19] Citernesi AS., Vitagliano C., Giovannetti M .1998. Plant growth root system morphology of Olea europaea L. Rooted cuttings as influenced by arbuscular mycorrhizas. S J Horticult Sci. Biotechnol., 73(5): 647-654.

[20] Dalpé Y., 2005. Les mycorhizes: Un outil de protection des plantes mais non une panacée. Phytoprotection, $\quad$ 56: $53-59$. http://id.erudit.org/iderudit/011715ar.
[21]Derkowska E., Sas Paszt L., Sumorok B., Szwonek E., Gluszek S., 2008. The influence of mycorrhization and organic mulches on mycorrhizal frequency in apple and strawberry roots. J. Fruit Ornam. Plantes, 16: 227-24

[22] Dixon RK., Garg VK., Rao MV., 1993. Inoculation of Leucaena and Prosopis seedlings with Glomus and Rhizobium species in saline soil: rhizosphere relations and seedlings growth. Arid Soil Res. Rehabil., 7: 133-144.

[23] Duponnois R., Colombet A., Hien V., Thioulouse J., 2005. The mycorrhizal fungus Glomus intraradices and rock phosphate amendment influence plant growth and microbial activity in the rhizosphere of Acacia holosericea. Soil Biol. Biochem., 37: 1460-1468.

[24] Echairi A., Nouaim R., Chaussod R., 2008. Intérêt de la mycorhization contrôlée pour la production de plants d'arganier (Argania spinosa) en conditions de pépinière. Sécheresse, 19 (4) 277-281.

[25] El Aich A., Bourbouze A., Morand-Fehr P., 2007. La filière chevreau de l'arganeraie, un produit typique et durable. Ann. Rec. For. Maroc, 3: 124-37.

[26] El Mrabet S., Ouahmane L., El Mousadik A., Msanda F., AbbasY., 2014 . The Effectiveness of Arbuscular Mycorrhizal Inoculation and BioCompost Addition for Enhancing Reforestation with Argania spinosain Morocco. Open Journal of Forestry, 4(1): 14-23.

[27] El Yousfi S. M., Benchekron F., 1992.La dégradation forestière dans le sud marocain. Exemple de l'arganeraie d'Admine (Souss) entre 1969 et 1989. Ann. Rech. For. Maroc, $26: 43-49$.

[28] Ferradous A., Bani-Aameur F., Dupuis P., 1997. Diversité génétique du fruit et de la graine de l'arganier. Dans Birouk A., Rejdali M. (éd.). Actes du séminaire sur les ressources phytogénétiques et le développement durable organisé à Rabat par le Comité national des ressources phytogénétiques, Rabat, Maroc. Actes Éditions, p. 319-324

[29] Fester T., Schmidt D., Lohse S., Walter M., Giuliano G., Bramley P., Fraser P., Hause, B.,Strack D. 2002. Stimulation of carotenoid metabolism in arbuscular mycorrhizal roots. Planta, 216: 148-154.

[30] Fidelibus M.W., Martin C.A., Stutz J.C., 2000.Effect of arbuscularmycorhizal (AM) fungal communities on growth of 'Volkamer' lemon in continually moist or periodically dry soil Scienta Hort., 84:127-140.

[31] Fortin J.A., Plenchette C., Piché Y., 2008. Les mycorhizes. La nouvelle révolution verte. Multi Monde Quae. (Eds.), Québec, 131 p. 
[32] Koske R, Gemma J.,1989.Carreiro M. Seasonal dynamics of selected species of VA mycorrhizal fungi in a sand dune, Mycological Research, 92(3): 317-321.

[33] Gerdemann J.W., Nicolson T.H., 1963. Spores of mycorrhizal endogone species extracted from soil by wet sieving and decanting. Trans. Br. Mycol. Soc., 46, 235.

[34] Haougui A., Souniabe P.S. ,Doumma A., Adam T., 2013. Evolution des populations des champignons endomycorhiziens sur les adventices de quatre sites maraîchers de la région de Maradi au Niger. Int. J. Biol. Chem. Sci., 7(2): 554-565.

[35] Herrera M.A., Salamanca C.P., Barea J.M., 1993. Inoculation of woody legumes with selected arbuscular mycorrhizal fungi and rhizobia to recover desertified Mediterranean ecosystems. Applied and Environmental Microbiology, 59: 129133.

[36] Honrubia M., 2009. The Mycorrhizae: A plantfungus relation that has existed for more than 400 million years. Anales del Jardín Botánico de Madrid, $66: 133-144$.

[37] Laaziza B.K., Gomez A.M., Quarraqi El M., Oihabi A., 2003. Réponses physiologiques et biochimiques du trèfle (Trifolium alexandinum. L.) à la double association mycorhizes rhizobiums sous une contrainte saline. Agronomie, 23: 571580.

[38] Lamhamedi M.S., Ammari Y., Fecteau B., Fortin JA., Margolis H., 2000. Problématique des pépinières forestières en Afrique du Nord et stratégies de développement. Cahiers Agricultures, 9: 369-380.

[39] Laminou M.O., Ibrahim D., Campanella B., Paul R., 2009. Effets de l'inoculation mycorhizienne et du substrat sur la croissance et la résistance au stress hydrique de cinq espèces fixatrices de dunes : Acacia raddiana Savi ; Acacia nilotica (L.) Willd. Ex Del. var. adansonii ; Acacia senegal (L.) Willd ; Prosopis chilensis Stunz. et Bauhinia rufescens Lam.. Geo. Eco. Trop., 33: 115- 124.

[40] Laminou M.O., 2010. Fixation des dunes dans le sud-est du Niger : évaluation de l'efficacité de la barrière mécanique, espèces ligneuses adaptées et potentialités d'inoculation mycorhizienne. Thèse de Doctorat, Université de Liège, Liège, Belgique, $\mathrm{p}$ 158.

[41]Le Houerou H.N., 1989. Classification écoclimatique des zones arides (s.l.) de I' Afrique du Nord. Ecologia Mediterranea, 15(35): 95-144.

[42] Martínez-García L.B., Pugnaire F.I., 2009. Interacciones entre las comunidades de hongos ormadores de micorrizas arbusculares y de plantas.
Algunosejemplos en los ecosistemas semiáridos. Ecosistemas, 18: 44-54.

[43] Martínez-García L.B., 2010.Micorrizas arbusculares en ecosistem- assemiáridos. Respuesta a factores de estrésambiental. Tesis Doc- torales, Almería: Universidad de Almería.

[44] M'hirit O., Benzyane M., Benchekroun F., EL Yousfi S-M., Bendaanoun M., 1998. L'arganier. Une espèce fruitière-forestière à usages multiples. Éditions Mardaga, Sprimont (Belgique), 1-151.

[45] Msanda F., El Aboudi A., Jean-Paul P., 2005. Biodiversité et biogéographie de l'arganeraie marocaine. Cahiers Agricultures, 14(4): 357 - 364.

[46] Newsham K.K., Fitter A.H. and Watterson A.R., 1995. Arbuscularmycorrhiza protects an annual grass from root pathogenic fungi in the field. J. Ecol., 83: 991-1000 .

[47] Norman J R., Atkinson D., Hooker JE., 1996. Arbuscular mycorrhizal fungi-induced alteration to root architecture in strawberry and induced resistance to the root pathogen Phytophthora fragariae. Plant and Soil, 8: 185-191.

[48] Nouaïm R. et Chaussod R., 1994. Mycorrhizal dependency of micropropagated argan tree (Argania spinosa). 2. Mineral nutrition. Agroforestry Systems , 27(1) : 67-77.

[49] Nouaïm R., 1994. Ecologie microbienne des sols d'arganeraies: activités microbiologiques des sols et rôle des endomycorhizes dans la croissance et la nutrition de l'arganier (Argania spinosa (L.) Skeels). Doctorat d'Etat es Sciences, Université Ibnou Zohr, Agdir, Maroc, 193 pp.

[50] Nouaim R., Lineres M., Esvan J-M., Chaussod R., 1994. Mycrorrhizal dependecy of micropropogated argan tree (Argania spinosa) - II. Mineralnutritition. Agroforestry Systems, 27: 6777.

[51] Nouaïm R., Chaussod R., 1996. Rôle des mycorhizes dans l'alimentation hydrique des plantes, notamment des ligneux en zones arides. Options Méditerranéennes, 20 : 9-26.

[52] Nouaim R., Chaussod R., 2002. Réponse à la mycorhization de plants d'arganier (Argania spinosa) multipliés par bouturage .Al Awamia, 105: 9-22.

[53] Nouaïm R., Echairi A., Kaaya M.,Chaussod R., 2007. Contribution à la domestication de l'arganier pour la production d'huile. Cahiers Agricultures, 16(3): $199-204$.

[54] Ouahmane L., 2007. Rôles des plantes associées (Lavandula et Thymus) dans la régénération du Cypres de l'atlas et effets sur la diversité 
rhizosphérique. Thèse de Doctorat National, Université cadi Ayyad, Marrakech,Maroc

[55] Peltier J.P., 1982.La végétation du bassin versant de l'Oued Souss (Maroc). Doctorat d'Etat es Sciences, Université de Grenoble (France), 201 pp.

[56] Phillips J.M., Hayman D.S., 1970. Improved procedures for clearing roots and staining parasitic and vesicular-arbuscular mycorrhizal fungi for rapid assessment of infection. Transactions of the British Mycological Society, 55: 158-161.

[57] Plenchette C. \& Fardeau J.C.,1988.Effet du pouvoir fixateur du sol sur le prélèvement de phosphore du sol par les racines et les mycorhizes. C. R. Acad.Sci. Paris, 306: 201-206)

[58] Plenchette C., Bois J.F., Duponnois R., Cadet P., 2000. La mycorhization (Glomus aggregatum) du mil (Pennis etumglaucum). Etudes et Gestion des Sols, 7(4): 379-383.

[59] Pozo M.J., Azcón-Aguilar C., Dumas-GaudotE., Barea J.M., 1999. $\beta$-1,3-glucanase activities in tomato roots inoculated with arbuscular mycorrhizal fungi and/or Phytophthora parasitica: Time course analysis and possible involvement in bioprotection. Plant Science, 141: 149-157. http://dx.doi.org/10.1016/S0168-9452(98)00243-X

[60] Rillig M., Mummey D.L., 2006. Mycorrhizas and soil structure. New Phytologist, 171, 41-53. http://dx.doi.org/10.1111/j.1469-8137.2006.01750.x

[61] Roldán A., Querejeta J.I., AlbaladejoJ.,Castillo V., 1996b. Growth response of Pinushalepensis to inoculation with Pisolithus arhizus in a terraced rangeland amended with urban refuse. Plant and Soil, 179: 35-43. http://dx.doi.org/10.1007/BF00011640

[62] Schellenbaum L., Berta G., Ravolanirina F., Tisserant B., Gianinazzi S., Fitter A .H ., 1991. Influence of endomycorrhizal infection on root morphology in a micropropagated woody plantspecies ( Vitis vinifera L.) . Annals of Bot., 68:135141.

[63] Schenck, N.C. and Perez, Y., 1990. Manual for the Identification of VA Mycorrhizal Fungi. (3 rdedn). Gainesville, Florida, Synergistic Publications.

[64] Schmid T., Meyer J., Oehl F., 2008. Integration of mycorrhizal inoculum in high alpine revegetation. Mycorrhiza works. In: F. Feldmann, Y. Kapulnik, \& J. Baar (Eds.), Proceedings of the International Symposium "Mycorrhiza for Plant Vitality" and the Joint Meeting of Working Groups 1-4 of COST Action 870 (pp. 278-288). Braunschweig: Deutsche Phytomedizinische Gesellschaft, 2 (5): 85-97.
[65] Sellal Z., Ouazzani Touhami A., Chliyeh M., Dahmani J., Benkirane R., Douira A., 2016. ArbuscularMycorrhizal fungi species associated with rhizosphere of Argania spinosa(L.) Skeels in Morocco. Int. J. Pure App. Biosci.,4(1): 82-99.

[66] Sghir F., Chliyeh M., Touati1J., Mouria B., OuazzaniTouhami A., Filali-Maltouf A., El Modafar C., Moukhli A., Benkirane R., Douira A., 2014 . Effect of a dual inoculation with endomycorrhizae and Trichoderma harzianumon the growth of date palm seedlings ISSN: $2320-$ 7051. Int. J. Pure App. Biosci., 2 (6): 12-26.

[67] Stavros D., Veresoglou., Shaw LJ., Robin Sen., 2011. Glomus intraradicesand Gigaspora margarita arbuscular mycorrhizal associations differentially affect nitrogen and potassium nutrition of Plantago lanceolata in a low fertility dune soil. Plant and Soil, 340: 481-490.

[68] Strullu D.G., Grellier B., Marciniak D., Letouzé R., 1986. Micropropagation of chestnut and conditions of mycorrhizal syntheses in vitro. New Phytol., 102: 9510.

[69] Strullu D.G., Plenchette C., 1991. Les mycorhizes en horticulture. PHM Revue Horticole, 352: 50-55

[70] Stutz J.C., Copeman R., Martin C.A., Morton J.B., 2000. Patterns of species composition and distribution of arbuscular mycorrhizal fungi in arid regions of southwestern North America and Namibia. Afr. Can. J. Bot., 78: 237-245.

[71] Sylvia D.M.,1986. Spatial and temporal distribution of vesicular-arbuscular mycorrhizal fungi associated with Uniola paniculata in Florida for dunes. Mycologia, 78: 728-734.

[72] Tahat M.M., Kamaruzaman S., Radziah O., 2010. The potential of endomycorrhizal fungi in controlling tomato bacterial wilt Ralstonia solanacearum under glasshouse conditions. African Journal of Biotechnology, 11: 13085-13094.

[73] Talbi Z., Chliyeh M., Mouria B., El Asri A., Ait Aguil F., Ouazzani Touhami, A., Benkirane R., and Douira A., 2016.Effect of double inoculation with endomycorrhizae and Trichoderma harzianumon the growth of carob plants. International Journal of Advances in Pharmacy, Biology and Chemistry Research, 5(1): 2277- 4688.

[74] Toro M., Azcón R., Barea J M., 1997. Improvement of arbuscular mycorrhiza development by inoculaltion of soil phosphate solubilizing rhizobacteria to improve rock phosphate bioavailability (32P) and nutrient cycling. Applied and Environmental Microbiology, 63: 4408-4412. 
[75] Trouvelot A., Kough JL., Gianinazzi-Pearson V., 1986. Mesure du taux de mycorhization VA d'un système radiculaire. Recherche de méthodes d'estimation ayant une signification fonctionnelle. Physiological and Genetical Aspects of Mycorrhizae (Gianinazzi-Pearson V \& Gianinazzi S, eds), INRA Press, Paris,; 217-221

[76] Turjaman M., Tamai Y., Santoso E., Osaki M., Tawaraya K., 2006.Arbuscularmycorrhizal fungi increased early growth of two nontimber forest product species Dyera polyphylla and Aquilaria filaria under greenhouse conditions. Mycorrhiza,16 :459-64.

[77] Walker, C., 1983. Systematics and taxonomy of arbuscular endomycorhizal fungi (Glomales) a possible way forward, Agronomie, 12: 887-897.

[78] Zahidi A et Bani-Aameur F., 1996. Germination des amandes d'arganier (Argania spinosa L. Skeels) : effet du génotype, de la date de semis et de l'année de récolte. Ann.. Rech. (Maroc). 